\title{
Endosulfan Degradation through Cipadessa Baccifera and Clausena Dentata
}

\author{
S. Archaya ${ }^{1}$, L. R. Gopinath ${ }^{1}$ and R. Bhuvaneswari ${ }^{2}$ \\ ${ }^{1}$ (Departement of Biotechnology, Vivekanandha College of Arts and Science for Women, Tiruchengode, \\ Namakkal, Tamil Nadu, India) ${ }^{2}$ (Department of Zoology, Namakkal Kavignar Ramalingam Government Arts \\ College for Women, Namakkal, Tamil Nadu, India )
}

\begin{abstract}
Identifying the usage of C. baccifera and C. dentata in the agricultural fields at Kolli hills, Tamilnadu, India the present study was able to obtain effective degradation of commonly used pesticide endosulphan. From the experiment it was evident that use of plant along with the twigs increases the $\mathrm{pH}$ for chemical transformation of pesticides. Among the two species $C$. dentata is better effective in removing pesticides. However, use of cow dung along with two species in same quantity increases pesticide degradation to a greater extent and also increases the micro and macro nutrient concentration in the soil for a sustainable bioremediation. The present study was also able to identify that through application of $C$. baccifera, $C$. dentata and cow dung each 3 tons can convert even the pesticide polluted soil into a status of organic certification
\end{abstract}

Keywords: Degradation, endosulphan, soil nutrients

\section{Introduction}

Changing socio economic condition and advance in science and technology increased population leading decreased land to man ratio (Nelson-smith, 1995) and increased human consumption of natural resources increasing pressure on agriculture sector which lead to continuous monoculture (Oerke, 2004). Loss of soil fertility and crop production lead to evolution of green revolution with highbred varieties to cope up the situation with industrialization of agriculture with application of fertilizers (Swaminathan, 2001). Uses of pesticide have been essential among the farmers to protect their crops from production loss. As a result farmers enjoyed increased production from 50 million tons in 1948-49 to 198 million tons in 1996-97 in 169 million hectares in India (Aktar, et al., 2009).

Bioremediation of pesticides have been attempted in the past few years through changing the $\mathrm{pH}$ of the soil, addition of organic matter, microbial removal, etc. However, use of herbal plant materials are less studied. There are varieties of practices among the traditional communities where it needs scientific understanding backup in refining the technology. The present paper attempts to backup one such practice where herbal plants were mulched to the soil for effective growth by the traditional communities in Kolli Hills. The reconnaissance survey identified the productivity increased in fields with pesticide application and levels of pesticide in the crop decreased to a greater extent which formed the basis of the present research to be carried out. Moreover wider application of cow dung also believed to be involved in removal of toxic chemical in the soil hence the present research was designed to identify the role of cow dung in combination with other herbal plants in degradation of three popularly used pesticides in past, present and future for sustainable ecological development and quickly recover the soil into organic certification.

\section{Materials And Methods}

The medicinal plant (Cipadessa baccifera and Clausena dentata) material leaves were obtained from Kolli hills, Namakkal, Tamil Nadu, India. The plant materials were shade dried and powdered. The cow dung collected from the Namakkal surroundings was also shade dried and powdered. The pesticide endosulphan 35

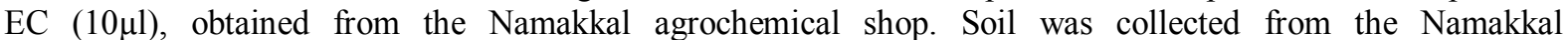
surroundings. The combinations were made for 13 treatments along with a control and 20-30\% moisture was maintained throughout the study for 90 days.

\section{Treatments}

1. Control

2. Endosulphan

3. Cipadessa baccifera $(12 \mathrm{gm})$

4. Clausena dentate $(12 \mathrm{gm})$

5. Cow dung (12gm)

6. Endosulphan + Cipadessa baccifera (12gm)

7. Endosulphan + Clausena dentata(12gm) 
8. Endosulphan + Cow dung (12gm)

9. Endosulphan + Cipadessa baccifera $(6 \mathrm{gm})+$ Cow dung $(6 \mathrm{gm})$

10. Endosulphan + Clausena dentata (3gm) + Cipadessa baccifera (3gm) + Cow dung $(6 \mathrm{gm})$

11. Endosulphan + Clausena dentata (3gm) + Cow dung (3gm)

12. Endosulphan + Cipadessa baccifera (stem) $(6 \mathrm{gm})+$ Cow dung $(6 \mathrm{gm})$

13. Endosulphan + Clausena dentata (stem) $(6 \mathrm{gm})+$ Cow dung (6gm)

Soil characteristics such as $\mathrm{pH}$, Micro nutrient analysis (Iron, Copper, Zinc, and Manganese by Atomic Absorption Spectroscopy), and Macronutrient analysis (Nitrogen by Alkaline permanganate method (Subbiah \& Asija, 1956), Phosphorous by Olsen's method (Olsen, et al., 1954), Potassium by Boiling Nitric acid method were compared with the control. The treated and control was analyzed for the presence of number of bacterial colonies for $30^{\text {th }}, 60^{\text {th }}$, and $90^{\text {th }}$ day. One gram of soil sample from each treatments were serially diluted and 0.1 $\mathrm{ml}\left(10^{-4}\right)$ was plated on the agar plates after $24 \mathrm{hrs}$ of incubation the colonies were counted. The pesticides amended treated soils were analyzed for pesticide residue through GC-MS extraction were done with DCM and the organic phase dried with Magnesium Sulphate. Metabolites were diluted with hexane to yield $20 \%$ hexaneDCM solution and applied to a silica gel column. Standards using endosulfan were calibrated for detectable concentrations endosulfan in soil extracts and analyzed for GC using FID (Ki-Souk, Nam and Jerry King, 1994).

\section{Results}

The soil used in the present experiment was found to be sandy loam with $49 \%$ sand $35 \%$ silt and $16 \%$ clay. Physical parameters of the soil were measured at $90^{\text {th }}$ day of the experiment. $\mathrm{pH}$ of control soils ranged between 8.2 to 7.7 , lowest was recorded with C. baccifera and highest in cow dung. In soil amended with endosulfan under different treatments $\mathrm{pH}$ ranged from 8.34 to 7.86 , lowest $\mathrm{pH}$ was observed when treated with in C. dentata and cow dung and highest when treated with C. dentata stem with cow dung. Addition of stem samples of the plant material showed increased $\mathrm{pH}$ in all the treatments (Figure 1).

Macro nutrient estimation in control soils showed high with addition of cow dung and in both plant material, phosphorous ranged between 5.33 to $10.33 \mathrm{Kg} /$ acre, lowest in soil with endosulfan and high with cow dung similarly potassium ranged between 107.33 to $135.67 \mathrm{Kg} /$ acre. However nitrogen was high in soils with endosulfan, less in soil without any addition. Nitrogen among the control soils ranged between 72.87 to $89.33 \mathrm{~kg} / \mathrm{acre}$. Among the pesticide amended soils treated nitrogen ranged between 76.33 to $94.67 \mathrm{~kg} / \mathrm{acre}$ high with C. baccifera and Cow dung treatment and low nitrogen content with C. baccifera stem and cow dung. Phosphorous ranged between 6 to $8.83 \mathrm{~kg} /$ acre in the treated soils in which high phosphorous recorded in $\mathrm{C}$. dentata treated and low in C. baccifera, C. baccifera stem and cow dung. Potassium ranged between 90.33 to $104 \mathrm{~kg} / \mathrm{acre}$ in treated soils in this C. dentata treatment showed high and C. dentata, C. dentata stem with cow dung (Figure 2).

Among the micronutrients iron in the control soils ranged between 8.03 to $6.23 \mathrm{ppm}$, lowest in C. dentata and highest in endosulfan. Manganese ranged between 4.1 to $5.73 \mathrm{ppm}$ highest in endosulfan and lowest in soil control. Zinc ranged between 1.19 to $0.37 \mathrm{ppm}$ highest in soil control and lowest in C. dentata, similar trend was observed for copper which ranged between 0.55 to $2.27 \mathrm{ppm}$. Among the treated soils Iron ranged between 9.2 to $7.7 \mathrm{ppm}$ in which highest C. dentata with cow dung and lowest C. dentata stem with cow dung, Manganese ranged between 8.00 to 5.30ppm, highest in C. dentata, C. baccifera with Cow dung and lowest in Cow dung treatments, Zinc ranged between 0.60 to $0.37 \mathrm{ppm}$, highest in C. dentata, C. baccifera with Cow dung and lowest in Cow dung treatments, Copper ranged between 0.87 to $0.63 \mathrm{ppm}$ highest in C. dentata with Cow dung and lowest in C. baccifera stem with Cow dung (Figure 3).

The microbial population in control soil ranged between 82 to 21 colonies, which reduced with increasing time highest colony count was registered in C. baccifera and lowest in Endosulfan control soil at $90^{\text {th }}$ day. Microbial population in the treated soils ranged between 86 to 21 with similar trend to control soils C. baccifera show high number of colonies and C. dentata with Cow dung lowest colony count at $90^{\text {th }}$ day (Figure 4).

Endosulfan estimation after treatment showed lowest in the samples treated with both leaf litter and cow dung where only $0.56 \mu \mathrm{g} / \mathrm{ml}$ out of $10 \mu \mathrm{g} / \mathrm{ml}$. Among the individual plant species C. dentata leaf showed the lowest both with cow dung $(1.08 \mu \mathrm{g} / \mathrm{ml})$ and when used alone $(1.126 \mu \mathrm{g} / \mathrm{ml})$. Control soil showed highest endosulfan concentration $7.31 \mu \mathrm{g} / \mathrm{m}$ followed by cow dung treated soils $(2.35 \mu \mathrm{g} / \mathrm{ml})$. However, rate of endosulfan concentration is less in all the soil samples from $30^{\text {th }}$ day to $90^{\text {th }}$ day (Figure 5).

\section{Discussion}

$\mathrm{pH}$ is an important factor in the soil for cation and an ion exchange which also play a vital role in bioremediation process like mineralization, degradation decomposition, (Kumar and Philip, 2006; Grundmann et al., 2007; Awasthi et al., 2000) Degradation of endosulfan in sandy loam soil is reported to range between 60 
and 800 days and rate of endosulfan decomposition is dependent on $\mathrm{pH}$ (Kimber et al., 1994). $\mathrm{pH}$ estimates in the present research showed in the alkaline side after 90 days of experiment in most of the soils after treatment including the control. However increased $\mathrm{pH}$ was observed in the treatment soils when compared to the control soils which also resulted in degradation of endosulfan at higher rates. Among the various treatments all the three C. dentata, C. baccifera and cow dung showed the highest degradation of $94 \%$ where the $\mathrm{pH} 8.01$ followed by C. dentata with cow dung and C. baccifera with cow dung $89.2 \%$ and $88.9 \%$ endosulfan degradation respectively with a $\mathrm{pH}$ of 7.86 and 8.01 . Single treatment with plant material also showed increased degradation of $87.8 \%$ with $\mathrm{C}$. baccifera and $88.8 \%$ with $\mathrm{C}$. dentata with a $\mathrm{pH}$ of 8.07 . This increased degradation was attributed with higher $\mathrm{pH}$ is due to hydrolysis of endosulfan which was also reported (Hirakura et al., 2006). High $\mathrm{pH}$ degradation of pesticides are mainly due to chemical transformation rather often enzyme modification (Martens, 1976). High pH degradation of pesticides are mainly due to chemical transformation rather often enzyme modification (Martens, 1976). However, highest $\mathrm{pH}$ of 8.2, 8.2 and 8.34 was recorded in Cow dung and stem powder of $\mathrm{C}$. baccifera and $\mathrm{C}$. dentata with $76.8,81.3$ and 83.2 percentage of endosulfan degradation only respectively.

Comparison with the microbial population C. baccifera showed highest population where as cow dung showed increased microbial population during $30^{\text {th }}$ to $90^{\text {th }}$ of the experiment. Therefore degradation by these materials may be attributed to microbial degradation which may be due to utilization of pesticide as carbon source by the microorganisms (Singh et al., 2003 and Sharaf et al., 2006). But studies show that pesticide cause damage to the microorganisms (Olaitan and Abiodun 2011). The microbial enzyme mediated pesticide degraded products are more toxic than chemically transformed compound. Therefore the degradation achieved by the present study through plant material at higher $\mathrm{pH}$ is greatly by chemical transformations which are environmentally safer products.

It is obvious that addition plant material and cow dung increases the nutrient concentration increase of nitrogen in endosulphan added soil is an interesting thing to answer further the same was observed with the pesticide amended soils under different treatment. Earlier studies show that presence of endosulphan pesticide residue reduces the nitrogen fixation by micro-organisms especially under cultivation condition in leguminous plants (Darure et al., 2012). Detail study conducted by Akipokpodion et al., (2010) revealed that endosulphan has no change in the soil nitrogen content. Studies also show that increase in pesticide resistant microbial strains (Elsaid et al., 2010) in pesticide polluted soils. However, in the present study there is an increase in microbial colonies compared to control soil which may lead to increase nitrogen concentration. The same is further reflected in the pesticide amended soils with different treatment which are mainly organic matter. Views on Phosphorous and potassium in the existing literature are mixed in nature most of the paper depicts reduction in both phosphorous and potassium (Bhanu et al., 2008) but in relation to reduction to microbial population were as increased phosphorous and potassium was also reported (Coteanu, 2010). However, the effect of pesticides is related to soil characteristics like, type of soil, moisture level, organic matter, and soil biodiversity. Therefore the present study was conducted in an ideal sandy loam soil were all the above parameters are kept at optimum where we could see that phosphorous and potassium decreased even when treated with organic matter and showed increase in microbial population indicates that the growth of microbes leads not only reduce the pesticide residue also utilizes considerable amount of macro and micronutrient. Among the micro nutrients metals generally increase since they also gets released from the soil due to microbial activity. Studies on nutrient and pesticide degradation show that degradation is higher at nutrient deficient soils (Martens, 1976).

\section{Figures And Tables}

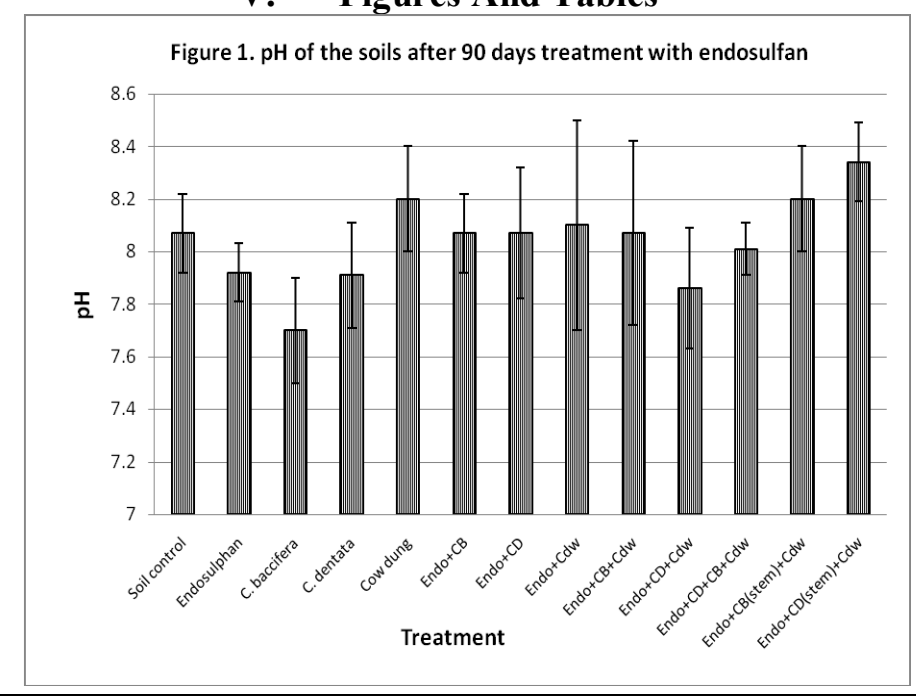



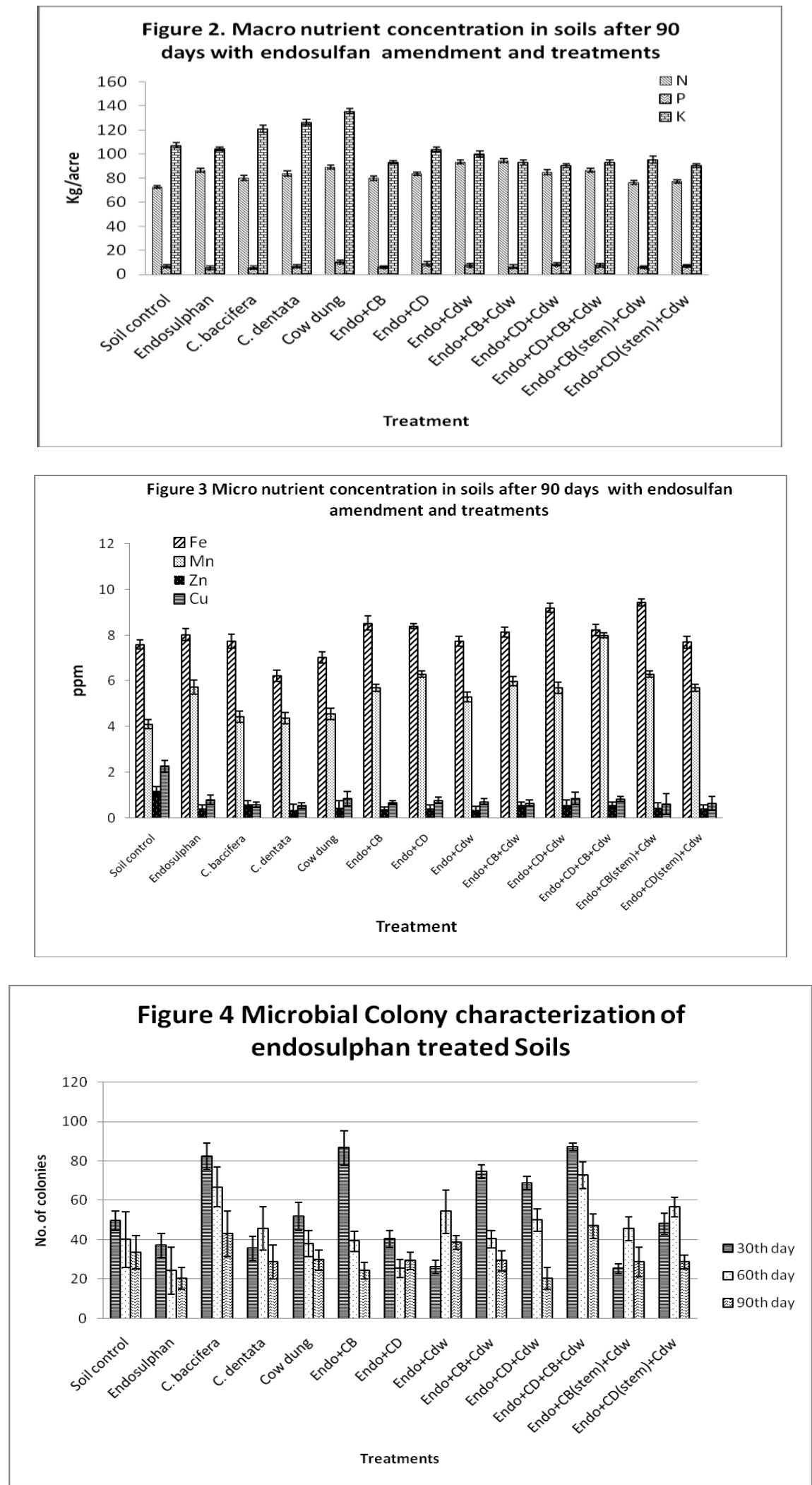


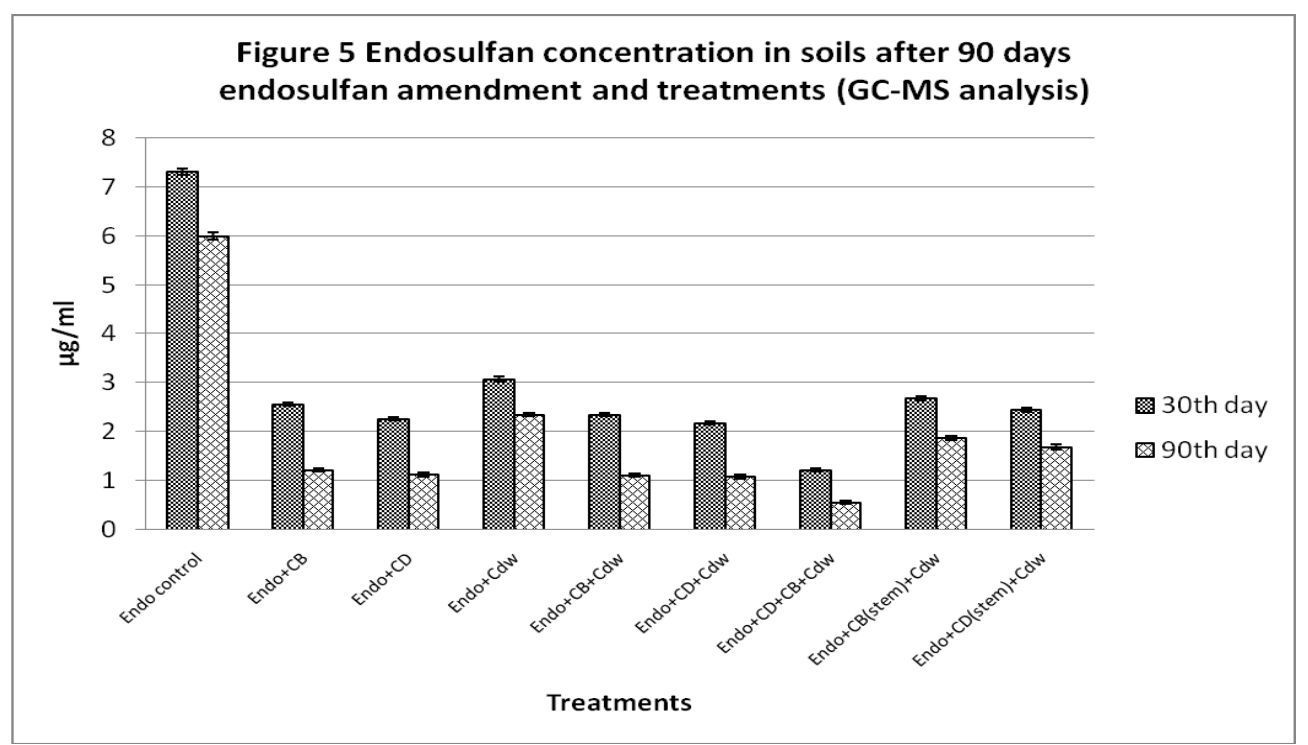

CB-Cipadessa baccifera CD- Clausena dentata Cdw-Cow dung

\section{Conclusion}

Pesticides are more toxic to soil as it affects microbial growth and reduced natural release of nutrients. They not only affect the soil fertility but also the living organisms through their toxic nature. From our results the use of $\mathrm{C}$. baccifera and C. dentata plant material along with cow dung are effective in degradation and improve the soil fertility.

\section{Acknowledgement}

We thank Dr. M. Karunanithi Chairman, Vivekanandha College of Arts \& Sciences for Women for providing infrastructure presentation for present research work. Thanks to TNDCE for providing Scholarship.

\section{References}

[1]. Akipokpodion, P. E., Uloko, B., Edibo, G., 2010. Degradation and residual effect of endosulfan on soil chemical properties a nd root-knot nematode Meloidogyne incognita populations in cocoa plantation in Ibadan, Nigeria. J. Applied Biosci. 26, $1640-1646$.

[2]. Aktar, W., Sengupta, D., Chowdhury, A., 2009. Impact of pesticides use in agriculture: their benefits and hazards.Interdiscip. Toxicol. 2, 1-12.

[3]. Anonymous 2001. Endosulphan Fact Sheet (ToxFAQS) Agency for toxic substances and disease registry (ATSdr), US Department of health and human Services, public health Services, Division of Toxicology, Atlanta Georgia.

[4]. Awasthi. N., Ahiya, R., and Kumar, A. 2000. Factors influencing the degradation of soil applied endosulphan isomers. Soil Biol Biochem. 32. 1697-1705.

[5]. Bhanu, B. P., Devkota, B., Jyoti, U. D., 2008. Botanical pesticides on soil fertility of coffee- Orchards. J. Agri. Environ. 9, 16-28.

[6]. Coteanu, V., Palagesiu, L., Radulov, I., 2010. Preliminary research concerning the effects of insecticide treatments on some soil parameters in truck farming. Res. J. Agri. Sci. 42, 26-31.

[7]. Darure, M. V., Chonde, S. G., Bhosale, P. R., Raut P. D., 2012. Effect of residual concentration of endosulfan on the nitrogenase enzyme activity in Arachis hypogea. Ann. Bio. Res. 3, 192-195.

[8]. Elsaid, O. G., Abdelbagi, A. O., Elsheik, E. A. E., 2010. Pesticide resistant bacterial strain. Intern. J. Environ. Sci. 1, $123-131$.

[9]. Grundmann, S., Roland, F., Schmid, M., Laschinger, M., Ruth, B., Schulin, R., Munch, J. C., Schroll, R.,1 2007. Application of microbial hot spots enhances pesticide degradation in soils. Chemosphere 68, 511-517.

[10]. Hirakura. Y, Nakamura. M, Wakasawa. T, Ban. K, Yokota. S, Kitamura. S. 2006. Excipient hydrolysis and ester formation increases $\mathrm{pH}$ in a parentral solution over aging. Indian J. Pharmacol. 325(1-2), 26-38.

[11]. Ki-Souk Nam and Jerry W. King, 1994. Coupled SFE/SFC/GC for the trace analysis of pesticide in fatty food samples. J. High Res. Chrom. 17, 577-582.

[12]. Kumar. M and Philip. L. 2006. Bioremediation of endosulphan contaminated soil and water optimization of operating conditions in laboratory scale reactors. J. Hazard. Mater. 354-364.

[13]. Martens, R., 1976. Degradation of $\left[8,9-{ }^{14} \mathrm{C}\right]$ Endosulphan by soil microorganisms. Appl. Environ. Microbiol. 31, 853-858.

[14]. Nelson-smith, D., 1995. Food or famine politics, economics and science in the world's food supply. Brighton crop protection conference. Weeds 1, 3-15.

[15]. Oerke, E. C., Dehne, W. H., 2004. Safeguarding production- losses in major crops and role of crop protection. Crop Protection. 23, $275-285$.

[16]. Olaitan, A. F., Abiodun, A. T., 2011.Comparative toxicity of botanical and synthetic insecticides against major field insect pests of Cowpea (Vigna unquiculata (L) Walp). J. Nat. Prod. and Plant Resourc. 1, 86-95.

[17]. Olsen, S. R., Cole, C. V., Watanabe, F. S., Dean, L. A., 1954. Estimation of available phosphorus with sodium bicarbonate. USDA Circular 939, 1-19 Gov Printing office Washington Dc.

[18]. Ramakrishnan, P. S., 1992. Shifting agriculture and sustainable development: An interdisciplinary study from North-Eastern India. UNESCO. Paris.

[19]. Sharaf, A. N., Soliman, M.H., Ibrahmin, M.A., Moustafa, S. A., Abd El-Hadi, A., Abd El-Hadi, 2006. Molecular identification and cloning of organophosphate degradation gene in some bacterial isolates. Arab J. Biotechnol. 10, 259-274. 
[20]. Singh, B. K., Walker, A., Morgan, J. A. W., Wright, D. J., 2003. Effect of soil pH on the biodegradation of chlorpyrifos and isolation of a chlorpyrifos- degrading bacterium. Appl. Environ. Microbiol. 69, 5198-5206.

[21]. Subbiah, B. V., Asija G. L., 1956. A rapid procedure for the determination of available nitrogen in soils. Curr. Sci. 25, 259-260.

[22]. Swaminathan, M. S., 2001.Biotechnology, genetic modification, organic farming and nutrition security. Phytomorphology golden jublee issue 19-30. 